\title{
PENERAPAN METODE MUSICAL FEELING DALAM BELAJAR TARI ZAPIN MELAYU DI SANGGAR TARI TAMORA 88
}

\author{
Putri Utami ${ }^{1}$, Tuti Rahayu ${ }^{2}$, Iskandar Muda ${ }^{3}$ \\ Prodi Pendidikan Tari/ Fakultas Bahasa dan Seni/ Universitas Negeri Medan \\ Jalan Willem Iskandar Pasar V Medan Estate 20221, Sumatera Utara-Indonesia \\ 'putriutami_kc@yahoo.com, ${ }^{2}$ tutirahayu12@gmail.com, ${ }^{3}$ iskandarmuda_msn@yahoo.com
}

\begin{abstract}
The thing that becomes the background of this research is the difficulty often faced dancers in a move that suits the taste of music, mainly on the acquisition of a sense of musicality (wirama) and appreciation (wirasa). The purpose of this study is to describe the mastery wiraga, wirama, and wirasa dancers, and how the application of mastery of musical feeling in studying dance and musical influence of feeling on the process of learning dance dance Zapin Melayu disanggar Tamora 88. The theory used in this research is the theory Musical Feeling (Carl.E.Seashore 1938: 2). This study aims to determine how the application of a person's sense of musicality while studying dance Zapin Melayu namely Tari Zapin dance disanggar Dedeng Missing Moon Tamora 88. The population in this study is the dance studio Tamora 88, of this population is taken Tamora 88 dancers from the studio. This research method is qualitative. Implementation of qualitative methods can not be separated in the data collection is done with obsesrvasi, literature, documentation. This study discusses the application of methods Musical Feeling in learning Malay Zapin dance at the dance studio dancers Tamora 88 to facilitate the mastery wiraga, wirama and wirasa. The results of this research is the mastery wiraga, wirasa, wirama dancers and the implementation of a method of musical feeling in learning dance Zapin Dedeng Missed the Moon by the dance studio Tamora 88, whose application greatly affect the quality of the dancers dance studio, especially in the sense of music appreciation and rote, both in the process of learning dance as well as the overall results of the dance.
\end{abstract}

Keywords: Musical feeling, Dancing Dedeng Missing Moon, Tamora

\section{PENDAHULUAN}

Tari adalah ekspresi jiwa manusia, dalam mengekspresikan diri dibutuhkan tempat atau wadah untuk seseorang yang ingin belajar menari, mengeksplorasi (menjelajahi) setiap teknik ruang gerak baik secara wiraga, wirama, dan wirasa. Salah satu tempat untuk mengembangkan potensi diri itu adalah sanggar tari.Sanggar adalah tempat melakukan suatu aktivitas dan kreativitas dalam berbagai bidang seni.Sebagaimana diketahui bahwa ada banyak sanggar yang dikenal masyarakat seperti sanggar musik, sanggar rias, sanggar senam, sanggar lukis, dan sanggar tari.

Sanggar tari adalah sarana melakukan aktivitas berkesenian oleh sekelompok orang yang meliputi pelestarian, penelitian, dan kerjasama.Sanggar tari sangat diperlukan kehadirannya oleh masyarakat, seniman, dan pemerintah sebagai sarana untuk menumbuh kembangkan kesenian tari di Indonesia (Hartono, 1984:132).Saat ini banyak sekali berdiri sanggarsanggar tari di Kecamatan Tanjung Morawa Kabupaten Deli Serdang, salah satunya keberadaan sanggar tari Tamora 88. Sanggar tari ini merupakan nama sebuah perkumpulan yang didalamnya terdapat kegiatan seni dan budaya. Sanggar tari Tamora 88 ini dipimpin oleh Syahrial Felani dan berdiri pada tanggal 08 Agustus 1988.

Bidang-bidang yang dipelajari di sanggar ini yaitu bidang seni tari, seni musik, dan tata rias. 
Sanggar tari Tamora 88 adalah sanggar tari yang mempunyai pengalaman-pengalaman di bidang seni tari. Banyak tari-tarian tradisional Melayu yang diajarkan, diantaranya : tari Serampang XII, tari Mak inang pulau kampai, tari kreasi zapin Melayu, dan tari lainnya. Pelatihan tari di sanggar merupakan kegiatan pendidikan non-formal karena pada umumnya kegiatan tari disanggar tidak dibagi atas jenjang, waktu penyampaiannya diprogram lebih pendek dan materi pelajaran pada umumnya lebih banyak yang bersifat praktis dan khusus.

Salah satu pembelajaran seni tari di sanggar Tamora 88 ini adalah berkreatifitas dalam proses pengembangan gerak serta penggarapan tari dan musik yang baru, dikarenakan seni tari saat ini sudah banyak mengalami pengembangan, seperti beraneka ragam bentuk tari yang tentunya juga dilakukan pembelajaran yang sesuai untuk meningkatkan kemampuan setiap penari baik secara wiraga, wirama, wirasa. Untuk menjadi penari yang mampu menguasai 3 aspek tersebut tentunya dibutuhkan sebuah metode atau cara yang efektif dalam proses latihan. Terutama pada penguasaan rasa musikalitas (wirama) dan penghayatan (wirasa) adalah satu hal penting yang harus dikuasi oleh seorang penari. Mengekspresikan sebuah tarian yang hanya bertumpu pada teknik gerak, merupakan sebuah bentuk tarian yang " tak bernyawa, tanpa roh “, ekspresi tari lebih sempurna jika teknik gerak bisa dipadukan secara maksimal dengan rasa atau penjiwaan. Pengusaan musical feeling adalah salah satu cara untuk memperkuat rasa, hafalan, serta kualitas seorang penari.

Dari kutipan artikel musical mind dalam buku "psycology of music" Carl E. Seasore (1938:2) yang diterjemahkan oleh Riyan hidayatullah yang mengatakan musik berbicara mengenai "rasa" karena esensi dari musik adalah bermain dengan "perasaan". Seluruh parameter musik tersebut (tone, rhythm, dan lain-lain) di- manage sepenuhnya menggunakan "rasa". The musical mind is first of all normal mind, artinya semua kemampuan merasakan, mendengar, mengerti dan sebagainya tercipta dalam suatu integrasi "sense"dari musik. Dalam artikel Riyan Hidayatullah menjelaskan ada dua aspek rasa dalam merasakan musik.Pertama sifat alamiah pengalaman estetik, dan yang kedua adalah yang bisa kita sebut sebagai "perasaan mencipta" sebagaimana yang terjadi pada seorang komposer. Kedua aspek tersebut akan memperkuat dan memberikan penegasan emosional mengenai ekspresi semakin nyata.

Berkaitan dengan hal tersebut penulis merasa tertarik untuk meneliti sebuah metode belajar tari yang sebenarnya dari dulu sudah digunakan dalam proses belajar tari tradisi, yaitu mereka tidak pernah belajar tari dengan menghitung, sebagai penulis saya dapat mengambil kesimpulan seperti ini karena peneliti mengamati kebeberapa pusat latihan tari tradisi, yang dilakukan oleh orang-orang tradisi seperti pada tanggal 09 agustus 2016 penulis berada di desa Lingga, Kabupaten Karo, Kecamatan Simpang Empat, disana penulis mengamati proses latihan belajar tari Karo mereka tidak mematokkan setiap satu ragam gerak akan berubah sesuai hitungan keberapa, mereka selalu mengikuti musik ketika musik berganti nada mereka akan berganti gerak, dan ketika tempo dari musik tersebut semakin cepat secara otomatis mereka langsung menyesuaikan dengan musik, sehingga rasa dalam melakukan gerak lebih dalam penjiwaannya.

Untuk itu pengunaan metode yang peneliti sebut sebagai musical feeling adalah teori belajar yang sudah dilakukan dari dulu hanya saja pelaksaannya sekarang ini sudah jarang dilakukan, metode yang 
cukup efektif dalam proses belajar menari yang berpengaruh terhadap wirama, wirasa serta hafalan penari. Rasa musikal dalam belajar tari sangat efektif tidak hanya mempermudah hafalan tetapi juga rasa penghayatan dan dapat memperkuat daya ingat untuk waktu yang cukup lama. Penggunaan metode ini tidak hanya untuk belajar tari-tari tradisi atau tari garapan, namun dalam belajar tari untuk anak-anak mereka di biasakan bergerak dengan lirik lagunya, peka terhadap nada dari musik iringan tarinya ini akan mempermudah anak-anak dalam belajar tari.

Beberapa sanggar masih banyak yang menggunakan metode ini dalam proses belajar menari, namun dalam penelitian ini peneliti mengambil sampel dari sanggar tari Tamora 88 yang dalam penggarapan tarinya lebih sulit untuk mengikuti musik dari tariannya, mereka menggunakan metode musical feeling dalam proses latihannya, salah satu penerapan metode ini pada saat belajar tari Zapin Melayu. taritari yang diciptakan oleh Syarial Felani yang merupakan seorang koreografer, penata, dan pemain musik tradisonal, dalam mengarap tari selalu menggunakan metode ini dalam pengarapan tariannya, beberapa karya Zapin Melayu yang digarap oleh Syarial Felani salah satunya "dedeng merindukan bulan" dan tari "Mas Merah"

Dalam proses latihan memiliki tahap-tahapan dalam menggunakan metode ini, perbagian tari memiliki tingkat kesulitan tersendiri dalam olah rasa musik dan penjiwaannya. Ini lah yang menjadi alasan penulis memilih sanggar tari Tamora 88 menjadi objek penelitiannya, karena menurut penulis untuk melakukan gerak dengan musik iringan tari Zapin Melayu ini bukanlah hal mudah untuk dilakukan, butuh rasa musikalitas tinggi, latihan yang panjang dan disiplin untuk bisa mendapatkan olah rasa musik dan penyiwaan dalam tarian ini.

Proses penerapan rasa musik yang diterapkan di sanggar tari Tamora 88 di awali dengan tahapan mendengarkan, merasakan, dan menyatukan antara gerak dan musik. Proses rasa musikal ini dilakukan secara berulang-ulang untuk memperkuat hafalan gerak, dan hafalan rasa musik terhadap tari tersebut. Berdasarkan latar belakang diatas, penulis dalam skripsi ini ingin mendeskripsikan bagaimana cara penerapan musical felling dalam proses belajar tari Zapin Melayu disanggar tari Tamora 88.

\section{Tujuan penelitian}

1. Mendeskripsikan penguasaan wiraga, wirama, dan wirasa penari di sanggar tari Tamora 88?

2. Mendeskripsikan pengaruh Musical felling untuk wiraga, wirama, dan wirasa penari Tamora 88.

3. Mendeskripsikan Penerapan Metode Musical Feeling Dalam Belajar Menari Tari Zapin Melayu di Sanggar Tari Tamora 88.

Untuk membahas tentang penerapan metode musical feeling dalam belajar tari zapin melayu di sanggar tari tamora 88. Penulis memakai teori Tari, teori Musical Felling, teori kemampuan musikal,dan teori faktor-faktor yang mempengaruhi kemampuan musikal.

Lokasi penelitian sesuai dengan judul yang disajikan dalam proposal penelitian ini adalah di sanggar tari Tamora 88 Tanjung Morawa. Waktu yang digunakan untuk mendapatkan untuk mendapatkan informasi dan data-data yang berkaitan dengan penelitian ini terhitung mulai bulan Juli 2016 sampai bulan September 2016.

\section{Teknik Pengumpulan Data}

- Observasi lapangan 
Objek yang diteliti adalah penerapan metode musical feeling, mulai dari deskripsi latihan dan penguasaan wiraga, wirama dan wirasa.

- Studi Kepustakaan

Pengumpulan data berdasarkan skripsi, bukubuku yang digunakan penulis berkaitan dan mendukung penelitian.

- Dokumentasi

Adanya dokumentasi pada pengumpulan data, maka proses penganalisaan dan penyusunan ke dalam laporan penelitian lebih valid dan terperinci.

\section{Teknik Analisa Data}

Penguraian data menggunakan teknik kualitatif yaitu sebagai prosedur pemecahan masalah yang di teliti dengan menggambarkan objek penelitian pada saat sekarang.

\section{PEMBAHASAN}

\section{Penguasaan Wiraga, Wirama, dan Wirasa Penari} Di Sanggar Tari Tamora 88.

Kemampuan penguasaan wiraga, wirama, dan wirasa setiap penari pasti berbeda-beda ini dikarenakan setiap orang memiliki kemampuan tersendiri dalam proses penguasaannya, seperti daya tangkap, kepekaan akan suara, dan menemukan tekhnik dalam prakteknya pun bisa berbeda, begitu juga dengan penari disanggar Tamora 88 ini dari keenam penari zapin dedeng tersebut mereka memiliki kemampuan wiraga, wirasa dan wirama yang berbedabeda. Berikut adalah nama-nama penari zapin dedeng merindukan bulan 1. Ira, 2. Adinda, 3.Nurul, 4. Arnisa, 5. Uma, 6. Mutiara.

\section{a. Penguasaan Wiraga}

Penguasaan wiraga penari diukur melalui indeks yang menentukan kualitas tarinya, kualitas tersebut meliputi bentuk sikap, kesesuaian gerak serta penghayatan geraknya, dari keenam penari tersebut penguasaan wiraga juga tidak merata ada, beberapa alasan ini dikarenakan perbedaan pengalaman penari, keseriusan dalam latihan dan kebiasaan selalu melakukan gerak dengan maksimal juga mempengaruhi penguasaan wiraga dari setiap penari. Dari keenam penari diatas, setelah dianalisa ditemukan banyak perbedaan dari segi penguasaan wiraga ini dikarenakan beberapa faktor yang mempengaruhi penguasaannya misalnya penari yang bernama Ira, Mutiara, dan Nurul dari ketiga penari ini secara pengolahan wiraga sudah baik, karena dari sisi pengalaman dalam menari dan tingkat keseriusan dalam melakukan gerak yang selalu maksimal dalam latihan, kebiasaan ini akan mempengaruhi kualitas dalam penguasaan wiraga, saat melakukan gerak yang maksimal bukan berarti harus dengan menggunakan tenaga yang besar tapi bagaimana penari bisa membedakan mana gerak yang harus diberi tenaga dan ruang yang besar dan mana yang tidak, ketiga penari diatas memahami bagaimana menguasai teknik pengolahan wiraga dengan baik, dari bentuk sikap, kesesuaian gerak serta dalam menyahati geraknya pun mereka sudah cukup baik dalam mengaplikasikanya.

Kemudian dari empat penari yang lain juga sudah cukup baik dalam penguasaan wiraganya, namun dari keempat penari tersebut salah satu penari yang bernama Uma, memang yang paling kurang penguasaan wiraganya, ini juga terjadi karena beberapa alasan, setelah diamati dalam proses latihan , dari keempat penari diatas memang ditemukan ketidak seriusan dalam melakukan gerak, tidak fokus dan tidak membiasakan latihan dengan gerak yang maksimal, sehingga penguasaan wiraganya juga kurang dibanding yang lain, Uma adalah yang terlemah, 
disebabkan diantara semua penari Uma adalah yang paling baru dari Sanggar Tamora 88 ini, jadi secara pengalaman juga masih jauh dari penari yang lainnya.

\section{b. Penguasaan Wirama}

Kemampuan penguasaan wirama penari, baik hubungannya dengan gerak dan musik, adalah bagaimana kepekaan penari terhadap musiknya yang akan menentukan kualitas penghayatan gerak dan keselarasan antara tari dan musik. Dari keenam penari diatas, setelah diamati dalam proses latihan, secara penguasaan wirama keenam penari tersebut sangat baik dalam olah iramanya, kemampuan mereka merata dalam penguasaan wirama baik Ira, Nurul dan Mutiara yang sudah memliki pengalaman yang cukup baik dalam menari maupun empat penari lainnya, termasuk Uma yang baru dalam belajar menari, ternyata setelah diamati dalam latihan mereka selalu mengikuti musik dan jarang mengunakan hitungan dalam latihan, secara tidak langsung metode musical feeling sudah teraplikasikan dalam proses latihan yang mempengaruhi penguasaan wirama mereka, dalam musical feeling ketika mereka mendengarkan musik kemudian menyatukan nya dengan gerak, alat indra seperti telinga, mereka akan mampu membedakan kuat nada, tempo, kemudian warna nada nya yang secara tidak langsung telinga akan peka terhadap perubahan suara tersebut, ketika mereka sudah peka dalam memahami nada, ketukan dan warna dalam musik tersebut, akan mudah dalam penghayatan gerak serta keselarasan musik dan tari. Selain mereka memahmi bagaimana latihan dengan mengikuti musik, kelebihan dari Sanggar Tamora 88 ini mereka sudah terbiasa latihan dengan musik iringan tari secara langsung sehingga jika ada yang tidak sesuai mereka akan mengulang hinga menyatu dengan musiknya sehingga secara irama mereka lebih kuat penguasaan dan penghayatanya.

\section{c. Penguasaan Wirasa}

Penguasaan wirasa penari adalah wujud penghayatan yang ditekankan pada penghayatan karakter peran, karakter gerak yang dilakukan, dan ekspresi yang ditampilkan menjadi bagian dari wirasa tari. Dari hasil pengamatan penguasaan wirasa dari keenam penari diatas, sudah baik penguasaan wirasanya, dari ke enam penari tersebut yang menjadi tokoh utama adalah Ira, yang memerankan tokoh bulan dalam tarian zapin dedeng ini, secara konsep tokoh bulan digambarkan sebagai gadis yang cantik, anggun dan berasal dari keluarga yang mapan, sehingga pemilihan penari yang tepat akan mempengaruhi peran yang akan dibawakan, Ira dalam menghayati perannya sebagai tokoh gadis yang bernama bulan sudah baik, karena secara pengalaman Ira sudah cukup banyak melakoni berbagai tokoh dalam sebuah konsep tari , sehingga dalam penguasaan wirasanya bukanlah hal yang begitu sulit bagi Ira, namun bukan berarti ekspresi yang ditampilkan juga mudah ada cerita kesedihan yang begitu dalam yang ingin ditampilkan pada tari ini, bagaimana mengambarkan seorang wanita yang merindukan kekasihnya dan cintanya tak direstui, mengambarkan perasaan ini juga memiliki tingkat kesulitan ter sendiri, namun Ira mampu membawakan nya dengan tepat.

Kelima penari yang lain juga sudah baik dalam penguasaan wirasanya, hal yang tersulit bagi mereka adalah bagaimana gestur tubuh saat menari juga mengambarkan kesedihan dari perasaan si tokoh bulan tersebut dan bagaimana ekspresi mereka sebagai sahabat menyemangi temannya, kelima penari tersebut sudah baik dalam berekspresi sehingga tidak begitu sulit penguasaan. 


\section{Penerapan Metode Musical Feeling Dalam}

Belajar Tari Zapin Melayu di Sanggar Tari Tamora 88

Penggunaan musical feeling sangat mempermudah dalam belajar sebuah tari bukan hanya wirama dan wirasa tapi juga ingatan musik, misalnya untuk waktu yang cukup lama penari bisa menarikan tari itu kembali ketika mendengar musiknya, contohnya seperti tari serampang XII, tari rantak atau tari kreasi lain yang menjadi tari wajib di tiap sanggar, ketika perbagian musik dari tari itu diputar penari yang sudah menghafal gerak serta memiliki ingatan musik akan mampu menarikannya lagi meski dalam jangka waktu yang panjang penari tidak menarikannya, ini adalah manfaat dari penggunaan musical feeling, berikut adalah proses penerapan musical feeling dalam belajar tari zapin di sanggar tari Tamora 88 adalah sebagai berikut :

\section{a.Tahapan Pertama (Kapasitas alat indra, the sensory capacities)}

penerapan metode musical feeling dalam belajar tari zapin, kapasitas sensorik menjadi bagian pertama yaitu Telinga yang kapasitas dasarnya yaitu, rasa nada, rasa waktu, rasa kuat bunyi dan rasa warnanada yang sifatnya elemental, artinya bahwa ini semua sebagian besar bawaan lahir. setiap penari sudah pasti memiliki alat indra pendengaran yaitu telinga walaupun setiap orang memiliki kuat lemahnya pendengarannya masing-masing. Dalam penerapan metode musical feeling telinga penari mampu membedakan rasa nada yang ada dalam musik iringan tari zapin tersebut, menurut penari dari sanggar tamora 88 ini ketika mereka mendengar musik setiap satu bar musik memiliki nada yang berbeda-beda memiliki rasa nada yang kuat dalam mendengarkan musik iringannya menjadi bagian penting dalam proses belajar menarinya, kemudian rasa waktu setiap bar musik ada beberapa nada melodis yang memiliki meter 8 kemudian meter 4 ketika mendengar musik sekali kemudian diulang telinga akan mendengar, lalu telinga akan mengirim ke otak sehingga penari mampu mengetahui berapa ketuk setiap gerak berganti dan berapa hitungan musik tersebut berubah. Rasa kuat bunyi ini juga hampir sama dengan rasa nada maupun rasa waktu ketika telinga mendengar musik otomatis penari akan mampu membedakan kuat lemah nya sebuah nada dan kelebihannya penari akan lebih memahami setiap bagian dari dari isi cerita dari tari ketika nyambung dengan kuat lemahnya nada dari musik iringannya. Yang terakhir adalah warna nada sama dengan ketiga kapasitas diatas telinga orang normal akan mampu membedakan warna nada yang tercipta dalam sebuah musik iringan. Berikut adalah partitur musik dan instrumen pengukuran kapasitas alat indra dalam belajar tari zapin disanggar Tamora 88.

\section{b. Tahapan Kedua (bayangan musikal, musical} imagert, Imajinasi imagination, memori, memory).

Bagian musical feeling yang kedua adalah kapasitas bayangan musikal, imaginasi dan memori ketiga aspek ini menjadi satu kesatuan karena saling berhubungan dalam sebuah pikiran musik. Bayangan musikal meliputi bayangan kinestetik dan sensasi kinestetik, yang berhubungan dengan kecenderungan motorik untuk menghayalkan nada. Kemudian imaginasi yaitu menciptakan suatu musik dengan mendengarkannya sehingga imaginasi membangun struktur musik ketika mendengar dan merasakan segala efek dari setiap rinci menulis sebuah nada atau membunyikannya dengan suara atau instrumen; ang terkahir yaitu memori kapasitas memori 
menghadirkan wujud materi nada warnanya yang sangat memperkaya pendengaran aktual akan bunyibunyi musik inilah yang menjadikan ingan kognitif untuk realistik musik. Penerapan metode musical feeling dalam proses latihan nya bayangan musikal adalah menghayalkan nada ketika penari sudah mendengar kan musik dalam proses belajarnya penari bisa menghayalkan nada dari musik iringan tersebut ini juga akan memperkuat rasa musikalitas dari penari semakin sering penari mendengar musiknya akan semakin mudah bayangan musikal akan di hafal oleh otak dan penari akan mangahayalkan nada bunyi dari musik iringannya. Kemudian imaginasi seperti penjelasan di atas penari akan membunyikan nada dengan suara biasanya musik didendangkan akan mempermudah secara hafalan dan rasa musikalitas, yang terakhir ada memori menurut penari ketika tari ini selesai berproses untuk jangka waktu pembutan tari zapin ini di buat kemudian diulang kembali ketika mendengarkan musik otak akan terangsang ingatan tentang tari tersebut, memori dalam otak setidaknya akan mengingat beberapa bagian musik yang khas sehingga ketika mendengar musik dibagian tersebut penari bisa mengulang kembali gerakan dalam tari tersebut. Dalam tahap bayangan musikal, imaginasi dan memori tidak ada instrumen yang mampu mengukur kemampuan tersebut dikarenakan kemampuan tersebut adalah kemampuan alamiah dari seseorang ketika mengingat maupun membayangkan sesuatu

\section{c.Tahapan Ketiga Kecerdasan musikal (musical intelligence)}

Kecerdasan musikal adalah kepekaan tentang musik tanpa harus memiliki keterampilan bermusik kecerdasan musikal ini diukur dari tonal, dan ritmis yang masing-masing dapat dikembangankan melalui pengenalan nada, melodi,harmoni, tempo dan ritmis. Pada penerapan nya setiap penari tidaklah harus memiliki kemampuan bermain musik, secara tidak sadar kecerdasan musikal sudah dimiliki oleh setiap orang termasuk penari dari sanggar Tamora 88 ini seperti pembahasan sebelum nya pengenalan nada, membedakan nada, mampu menguasai tempo sudah ada pada setiap penari ini akan menjadi metode belajar yang lumayan efektif karena setiap orang sudah memiliki dasar dari kecerdasan musikal tersebut. Begitu juga pada proses penarapan metode Musical Feeling disanggar tari Tamora 88 ini. Berikut intrumen pengukuran kecerdasan musikal terhadap penari dari sanggar Tamora 88 pada proses belajar tari zapin dedeng merindukan bulan.

\section{PENUTUP}

\section{A. Kesimpulan}

Ada Penerapan Metode Musical Feeling Dalam Belajar Tari Zapin Melayu Di Sanggar Tari Tamora 88 adalah sebagai berikut :

1. Salah satu cara belajar yang cukup efektif dalam belajar menari yaitu dengan menggunakan metode musical feeling, penguasaan musical feeling adalah salah satu cara untuk memperkuat rasa, hafalan, serta kualitas seorang penari. Salah satu sanggar yang menerapkan metode ini adalah sanggar Tamora 88 .

2. Proses penerapan rasa musik yang diterapkan disanggar tari Tamora 88 diawali dengan tahapan mendengarkan, merasakan, dan menyatukan antara gerak dan musik. Proses rasa musikal ini dilakukan secara berulang-ulang untuk memperkuat hafalan gerak, dan hafalan rasa musik terhadap tari tersebut.

3. Musical feeling sangat berpengaruh terhadap penguasaan wiraga, wirama, dan wirasa penari, hal ini dikarenakan dalam musical feeling terdapat beberapa 
faktor yang akan memperkuat ketiga hal tersebut, namun yang paling terpengaruh yaitu pada penguasaan wirasa serta wirama penari, ini dikarenakan dalam musical feeling terdapat kapasitas alat indra seperti telinga yang mampu membedakan rasa nada, rasa kuat bunyi, serta rasa warna nada, walalupun dari setiap penari memiliki penguasaan yag berbeda, namun jika secara penerapan musical feeling sudah baik, ini akan mempermudah penari dalam belajar menari.

4. pengaruh musical feling terhadap kapasitas alat indra yang alatnya adalah telinga, ketika penari mendengar musik iringan dan mulai menyatukan dengan gerakan secara berulang-ulang, secara langsung telinga akan membawa suara tersebut kedalam otak sehingga terjadilah ingatan tentang suara, ketika suara sudah sampai kedalam otak maka dampak yang timbul adalah daya ingat atau memori dan bayangan musikal sehingga penari sudah sering mendengar dan hafal pada musiknya ketika lagu tersebut diputar kembali penari akan mengingat kembali gerakan yang ada. Dengan adanya memori atau ingatan tentang suara dan bayangan musik akan mempermudah mereka dalam berproses menari, secara wirasa juga akan lebih bagus, karena dengan menghafal bunyi yang ada penari akan mampu terbawa oleh karakter musik yang ada, misalnya pada musik yang menggambarkan kesedihan jika penguasaan musical feeling sudah baik secara langsung penari tersebut akan mudah berekspresi sesuai karakter dari tarian tersebut, dan karakter gerak pun akan mengikuti peran yang dibawakan,

5. Penggunaan musical feeling sangat mempermudah dalam belajar sebuah tari bukan hanya wirama dan wirasa tapi juga ingatan musik, misalnya untuk waktu yang cukup lama penari bisa menarikan tari itu kembali ketika mendengar musiknya, contohnya seperti tari Serampang XII, tari Rantak atau tari lainya.

\section{B. Saran}

Penelitian yang penulis lakukan masih dalam tahap kecil namun bermanfaat bagi masyarakat pendukung kebudayaan serta pihak departemen pemerintah yang mengemban tugas menjaga dan melestarikan Budaya Nusantara.Kiranya penelitian ini dapat membuka jalan untuk penelitian berikutnya. Maka peneliti dapat memberi beberapa saran yaitu :

1. Kepada seniman tari atau pemilik sanggar lebih di perhatiakan lagi penguasaan wirama, wiraga dan wirasa untuk setiap anggota sanggar sehingga akan muncul penari-penari dengan kualitas yang bagus untuk masa yang akan datang.

2. Kepada seniman tari membiasakan setiap penari yang ada disanggar berproses menghafal dengan cara mendendangkan alunan atau nada dalam musik iringan tarinya sehingga dari segi hafalan agar lebih mudah.

3. Kepada penari yang baru atau sudah lama berproses belajar menari agar membiasakan menggunakan musical feeling untuk mempermudah hafalan, penguasaan wirama serta wirasa dalam karakter sebuah tari baik tari tradisi maupun tari kreasi baru.

4. Kepada masyarakat tari baik yang tergabung dalam sanggar-sanggar tari ataupun secara individu untuk membuat satu kesgiatan seperti workshop untuk mensosialisasikan manfaat metode musical feeling dalam proses belajar tari.

5. Kepada pemerintah khususnya pemerintah daerah untuk memberi atensi dengan memfasilitasi hasil kajian ataupun sebuah penelitian kesenian dan kebudayaan terutama diperguruan tinggi khususnya dibidang tari. 


\section{DAFTAR PUSTAKA}

Arikunto, Suharsimi. 1996. Prosedur Penelitian Suatu Pendekatan Praktik. Jakarta: Bina Aksara.

Armstrong, Thomas. (2002). 7 Kinds of Smart ldentifing and Developing Your Multiple. Intelegence. Jakarta : PT Gramedia Pustaka Utama.

Djohan.(2009). Psikologi Musik. Yogyakarta: Best Publishe.

Durban, Irawati. 2008. Tari Sunda Tahun 1940-1965 Rd. Tjetje Soemantri dan Kiprah BKI/PIT. Bandung: Pusbitari Pressr.

Johnson, R., James A., \& Belita, G. (2009). Assesing Performance. New York: The Guilford Press.

Lumbantoruan, Jagar. (2009). Latar Belakang Pengalaman Musikal dan Kemampuan Dasar Vokalia Mahasiswa Baru Program Studi Sendratasik FBSS Universitas Negeri Padang. Padang: UNP. Diakses dari http

Pumamasari, Desi. 2014. Pengaruh Musik Sihutur Sanggul pada Penciptaan Tari Kreasi daerah Batak Toba di Kota Medan. Medan: Universitas Negeri Medan.

Pennata Heldisari, Hana, 2013, "Hubungan Antara Kemampuan Musikal Dengan Kecerdasan Interpesonal Pada Murid Kelas 1-3 SD Negeri Pangen Gudang Purworejo "Jurusan Pendidikan Seni Musik Fakultas Bahasa Dan Seni yogyakarta: Universitas Negeri Yogyakarta.

Ramdiaz, Cindy, 2012. "Jose Rizal Firdaus Sebagai Pelopor Tari Kreasi Melayu di Medan. Medan : Universitas Negeri Medan.

Sukardi.(2011). Metodologi Penelitian Pendidikan. Jakarta: Bumi Aksara.

Sumaryanto, Totok. (2000). Kemampuan Musikal (Musical Ability) dan Pengaruhnya Terhadap Prestasi Belajar. Jurnal Harmonia: Unnes.

Lehmann, Andreas C. Sloboda, John A. Woody Robert H. 2007. Psychology for Musicians. INC: Oxford University Press.
Rarnadani, Nazila. 2015. Perkembangan Tari Zapin Di Kabupaten Deli Serdang Terhadap Etika dan Estetika. Medan: Universitas Negeri Medan.

Seasore, Carl E. 1938. Psychology of music. INC: Mc.Graw-Hill Book Company.

Soedarsono. 1978. Diktat Pengetahuan dan Komposisi Tari. Yogyakarta: ASTI.

Sugiyono, 2012. Memahami Penelitian Kualitatif. Bandung: Alfabet. 